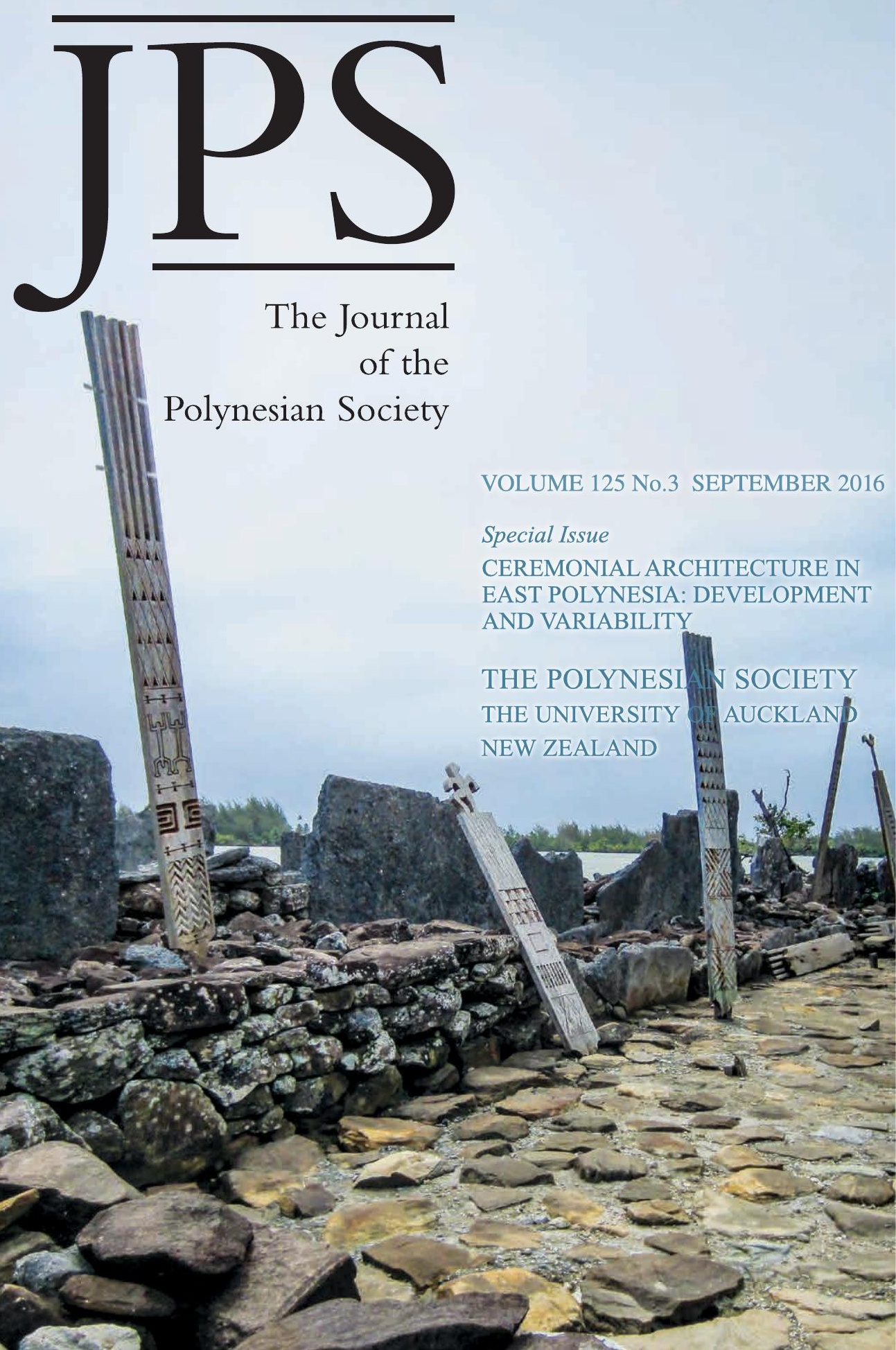




\title{
FROM THE VALLEY TO THE SHORE: A HYPOTHESIS OF THE SPATIAL EVOLUTION OF CEREMONIAL CENTRES ON TAHITI AND RA'IATEA, SOCIETY ISLANDS
}

\author{
TAMARA MARIC \\ Laboratoire d'Ethnologie Préhistorique UMR 7041 \\ Service de la Culture et du Patrimoine \\ Centre International de Recherche Archéologique Polynésienne (CIRAP)
}

In the 18th century the Society Islands had developed a complex chiefdom system that was considered to be one of the most stratified in East Polynesia, along with those of the Hawaiian Islands. The Society Islands are situated in central East Polynesia, and are currently divided into the Leeward Islands (to the northwest) and the Windward Islands (to the southeast) (Fig. 1). This division is geographical, but in traditional times there were minor cultural differences between the islands as well. The principal islands are high volcanic formations, Tahiti being the largest $\left(1042 \mathrm{~km}^{2}\right)$, while Ra'iatea, the youngest, is the largest of the Leeward Islands. These volcanic islands have deep, rugged valleys, and chiefdoms and territories typically were organised according to this topography.

By the end of the 18th century, the Tahitian chiefdoms were generally organised into eight principal political divisions, themselves often subdivided into three sub-districts. On Tahiti, 20 principal chiefdoms existed, most of them grouped into four confederations, but some were relatively independent (Oliver 1974) (Fig. 1). The settlement pattern described by ethnohistorical accounts places the ceremonial centre-including a principal temple or marae of the district and associated ritual houses and canoe artisans - at a coastal promontory and facing towards the reef pass. The social elite (ari $i$ i) resided on the coastal promontories, while the common people (manahune) lived in the valley interiors. This model typified the Windward Islands (Tahiti and Mo'orea), as described by Tahitian scholars (e.g., Ari'i Taimai in Adams 1964, Ta'aroa 1971 and Tati Salmon 1913) referring to their own islands, but little is known about the Leeward Islands (Ra'iatea, Taha'a, Huahine and Bora Bora). Thus we do not know if this traditional model can be applied to those islands, which have some differences in language, social organisation and ceremonial architecture (Handy 1930: 85, 104). This article examines the evolution of socio-political territories as seen through ceremonial architecture (marae). The goal here is to provide a synthesis and initial overview of preEuropean spatial and diachronic transformations of settlement patterns on Tahiti Island (Windward Islands) and compare these with patterns on Ra' iatea Island (Leeward Islands). 


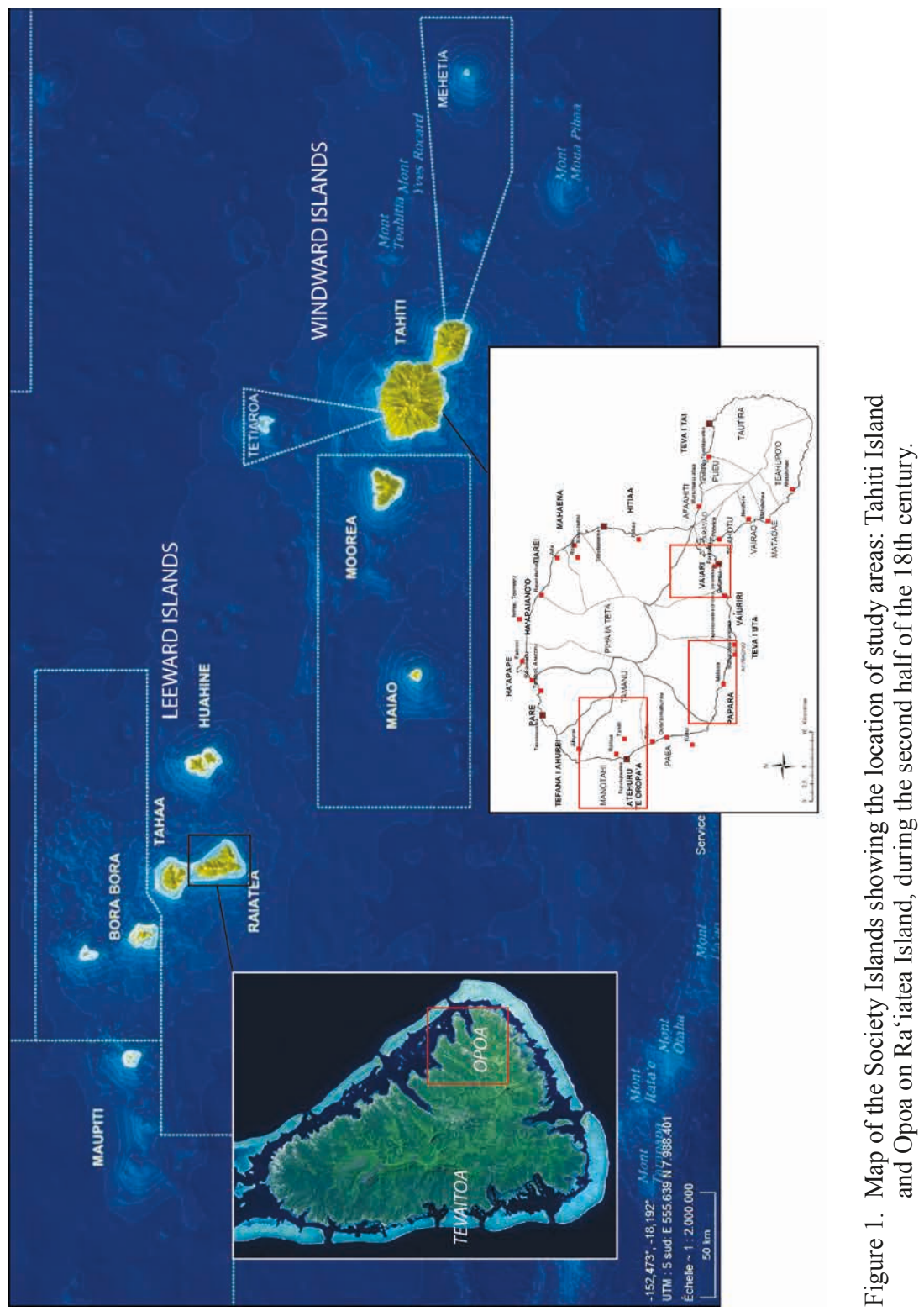


Since the pioneering archaeological studies of the 1960s (Garanger 1964, Green et al. 1967), the traces of elite settlements have been recorded, sometimes far inland, leading archaeologists to challenge the traditional settlement model described above. From 2000, settlement patterns of the Windward Islands have been increasingly documented, allowing for a better understanding of past social spaces, especially relationships between settlements of lower social classes, agricultural systems, and the habitats of intermediate social classes ( $r a$ 'atira), the latter scattered throughout valleys (Cauchois 2010, 2015, Kahn 2006, 2010, 2011, 2013, Maric 2012). As a result, archaeologists working in the Society Islands now have good criteria for identifying the habitats of different social classes, through a combination of ceremonial architecture and household complexity.

Particularly important to this study is the ceremonial architecture of temples (marae), and their geographic distributions. Given the importance of religion in pre-contact societies, the architectural elaboration of ceremonial architecture can be an important marker of major changes in socio-political and religious systems. The architectural forms of marae, and their archaeological contexts, allow for the identification of the residences of different social groups, as for example, the marae of the ari ' $i$ versus the simple marae of the manahune. Sometimes residences of the "middle-class" or ra 'atira also can be identified based on the analysis of settlement patterns.

\section{ETHNOHISTORICAL SOURCES}

The analysis of the three Tahitian chiefdoms presented here was carried out as part of my doctoral thesis research (Maric 2012). The aim of the present study is to reconstruct past territorial spaces and changes through time, using an inter-disciplinary approach which involves archaeological data, ethnohistorical records and an interpretation of toponymy - the latter inspired by the work of Torrente (2012) and Vaimeho-Peua (2008). The latter involves interpreting the original sense of place names to reconstitute the ancient function of spaces or locations, which are memorised in land names (ceremonial places, residences of the elite, agricultural/fishing places and so on).

According to many general ethnohistorical records, the territorial anchorages of Tahitian chiefdoms were supposedly unchanging, as the symbolic values of the landscape were highly sacred. The natural boundaries (rivers, mountains and reef passes) marked territorial limits, which were highly sacred (tapu). These were memorialised in traditional paripari fenua or 'praise chants' relating to the land and territories of a chief. Such chants list the principal geographical attributes of the territory, including the rivers or water places, sacred mountains, islets, ceremonial centres, district level temples or marae, meeting grounds or tahua, and the ritual 'ario $i^{1}$ places, 
along with the names of the principal chiefs. However, the study of local ethnohistories shows that change did occur, particularly with respect to the location of ceremonial complexes. Moreover, while archaeological surface studies of settlement patterns can have the problem of palimpsests in each landscape and territory, local ethnohistorical analysis helps to demonstrate changes over time. Here the settlement pattern cases from Tahiti are compared with those from Opoa on Ra'iatea Island, as the ethnohistorical records indicate a direct and strong influence of this chiefdom on the historical trajectory of Tahitian chiefdoms.

The methodology used here, specifically cross-referencing of archaeological and ethnohistorical data, helps to bring a diachronic perspective to our understanding of socio-political organisation in several ancient chiefly territories. The analysis of toponymy, along with ethnohistorical sources and genealogies of the ruling ari ' $i$ families, sometimes allowed for relative dating of the establishment of the principal chiefly marae. Despite a lack of archaeological studies and absolute chronologies for Tahitian and Raiatean marae, a framework from neighbouring islands can be applied. On Huahine Island, geographically close to Ra 'iatea, the first monumental marae in Maeva and Matairea are dated from the 15th to 16th centuries AD (Wallin and Solsvik 2005). On Mo'orea Island, close to Tahiti, rich data from 'Opunohu Valley dates construction of the first marae to the 13th to 14th centuries AD (Kahn 2011), while the development of more elaborated ceremonial architecture occurred in the 17th century (Kahn 2013, Kahn and Kirch 2014).

Most of the traditional lore and ethnohistorical records in Tahiti were written during the second part of the 19th and beginning of the 20th centuries. More generally, central East Polynesian traditional accounts mostly indicate three to four chronological periods of major political and religious transformations (Gunson 1993: 140-41). With a few exceptions, as for example Rapanui (Métraux 1999) or Napuka in the Tuamotu Islands (Te Reo o Te Tuamotu 2000), the first settlement of people on East Polynesian islands was mostly forgotten, or obliterated by later genealogies. Similarly it appears that on Tahiti Island archaic period traditions were replaced by the religious foundation myths related to the ruling chief genealogies as known in the 18th century, but on Rai' atea and Huahine traditional accounts still exist from more remote times (Saura 2005). On the other hand, Tahitian genealogies are less ancient than in the Leeward Islands (Pichevin 2013).

The second period of the ethnohistoric accounts describes the coming of a chief from another island, who marries a woman or man from an indigenous chiefly line or clan. The newcomer brings a new socio-political order, through the worship of their gods and a new marae. This social, political and religious change may be seen as the local appropriation of 
the political power and lands, legitimated through descent from marriage with an indigenous person (Eddowes 2003). The replacement of a prior genealogy by this new ruling family has been called "the ideology of the winner" (Torrente 2010: 279-80), and might be the result of either an outright war or a prestige competition. As a consequence of this, trying to retrospectively reconstitute the previous socio-political organisation often requires a considerable ethnohistorical analysis of many and varied sources which relate to non-contemporaneous events.

On Tahiti, a major change in local histories arises from the arrival of founding ancestor Firiamata no Hiti from Bora Bora Island (Leeward Islands) who married a woman from a ruling family on the south coast of the island, Vaiari. Farepu'a Marae, dedicated to the god Ta'aroa, is supposedly the first marae ari $i$ i of the island. Some generations after this, other marae ari ' $i$ were established around the island and involved taking a founding stone from the original Farepu'a Marae. On the island of Ra'iatea, in contrast, the major historical event is linked with the arrival of the god Ta'aroa, which is partly why the alternative name of this island was Havai' $i$, and it remains for many Polynesians a "sacred island".

The last major period of socio-political transformation in the Society Islands - before European contact - relates to the introduction of a new god, 'Oro, who was associated with fertility, peace and war (Henry 2000: 127, 237). The origin of this cult lies in Taputapuatea at Opoa, on Ra'iatea Island. The first marae Taputapuatea on Tahiti was founded in Tautira by the priests of Opoa (Henry 2000: 136). The other marae Taputapuatea in the Windward Islands was founded following an alliance between a Tahitian chief with the Tamatoa Chiefdom of Opoa (Henry 2000: 136-38). Thus, in Tahiti major socio-political transformations in late prehistory are traditionally attributed to influences from the Leeward Islands of Bora Bora and Ra'iatea.

\section{ARCHAEOLOGICAL EVIDENCE}

Marae of the Society Islands were of a variety of architectural types, based around three main components: the $a h u$, which was the most sacred part of the marae, materialised by a platform or enclosure, and located at one end of the court; upright stones; and a courtyard. The first archaeological inventory (Emory 1933) recorded three marae types that co-varied with geographic location. However, since the 1930s, the spatial location of those architectural types is no longer a criterion, but the geographic nomenclature is still used. The "interior" marae type has a simple architecture, using mostly basalt stones, and consists of an $a h u$, usually a low platform or area delimited by an alignment or low enclosure. The oldest dated marae in 'Opunohu Valley is of this type (Kahn 2013). 
The "coastal" type marae appears around the 17th century in the Windward Islands (Kahn and Kirch 2014), and was further developed during the 18th century. Kenneth Emory (1933) described these monumental marae on the coastal plains of Tahiti and Mo'orea. Most of them were directly associated with chiefly genealogies (Emory 1927). Since the 1960s, archaeologists carrying out further investigations and prospections (Garanger 1964, 1980, Green et al. 1967) have sometimes recorded these marae types at considerable distances inland, but the label of "coastal" has remained in the archaeological literature. Finally, a group of "intermediate" marae can be defined; these include worked coral or basalt slabs in the facing of the $a h u$ and two-to-three stepped ahu platforms (Emory 1933, Green et al. 1967).

In the Leeward Islands, the "coastal" marae have large ahu platforms with one or two levels (demarcated with large dressed coral slabs) and a courtyard (sometimes paved), and no constructed walls but sometimes double alignments. In the Windward Islands, the "coastal" architectural form has worked stones and coral in marae enclosures and/or retaining walls for the $a h u$ platform. Worked rounded basalt stones are set in several courses, and the first course of the wall is made of square coral blocks set on edge. This architectural component also has minor variations: the first course may use square basalt blocks - natural or sculpted — or both basalt and coral blocks. In some "coastal" type marae that are located inland, as in the Papeno"o Valley of Tahiti or in the 'Opunohu Valley of Mo'orea, natural rounded cobbles have been used instead of worked ones, apparently in imitation of "coastal" type marae that are actually located on the coast (Maric 2012: 66). One ethnohistorical account associates this architecture with worship of the god 'Oro; Henry (2000: 139) suggested that the rounded stones symbolised turtle heads, which could replace human sacrifices during 'Oro rituals.

On Tahiti, we know where the most ancient and powerful chiefly marae were located but unfortunately most of them were destroyed around the beginning of the 19th century. As a result, for some of them we lack architectural details. However, invaluable information comes from the first archaeological records of Emory (1933), and also from descriptions in ethnohistorical sources (Henry 2000, Salmon 1913). The disappearance of these major marae is a significant problem for our analyses, as without excavations and dating, the period of their establishment is unknown.

Polynesian religion, which structured the whole social life of Polynesians, had temples both for different social levels and for different purposes: family (including the different social classes), "kin-congregation" (Oliver 1974), specialist activities and territorial markers. This may explain the variety of architectural forms observed archaeologically. The fundamental aspect of marae is their function as places of interaction between two worlds: Te 
$A o$, the world of the living, and $T e P \bar{o}$, the world of the ancestors and gods. The marae itself was surrounded by boundaries which marked the sacred space. This fundamental function is also spatially materialised, with marae frequently being located at territorial limits or the edges of ancestral lands (Garanger 1964: 10). The great marae ari $i$ of the territorial level were part of ceremonial complexes involving numerous stone and wood structures, which focused all the attributes of the chiefly power. Thus, we can consider that the marae ari $i$ corresponded to the religious and political centres of chiefdoms.

\section{VAIARI, TEVA I UTA CONFEDERATION, TAHITI ISLAND}

In the middle of the 18th century, the Teva Confederation was said to be the most powerful on Tahiti Island. It included "Teva i Uta" (including the chiefdoms of Vaiari, Papara, Atimaono and Vaiuriri) located on the southwest coast of Tahiti Nui, and the "Teva i Tai" Confederation of the peninsula (Tahiti Iti). According to oral traditions, all of these socio-political groups were descendants of the founding ancestor Teva (Ta'aroa 1971). The mythological supremacy of Vaiari came from the ancestor Firiamata o Hiti, who derived from Bora Bora Island (previously named Vava' $u$ ). Farepu'a Marae, dedicated to the god Ta'aroa, was founded in the honour of a mythical ancestor named Tetuna'e, supposedly his direct descendant.

Farepu'a Marae unfortunately was destroyed by "King" Pomare in 1820 (Salmon 1910: 41, Ta'aroa 1971: 265). A sacred chant indicates its location, at the beginning of the main valley of the district, with a view of the coastal plain (Salmon 1910). This location is cross-referenced with both historical data and genealogical information. From the latter, a marae Farepu'a is mentioned in the land of Hapuriuri, according to the genealogy of $\mathrm{Nu}^{6} \mathrm{u}$

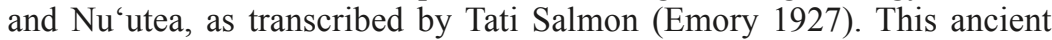
land has been recorded in the land claim register (Tomite fenua i Papeari, 1855-1856) and its relative location can be made using the ancient cadastre plans. This location corresponds to the lower valley of Titaaviri, at the same place indicated by our local informants during fieldwork in 2005 (Maric 2012: 230). A sacred chant describes this marae as being constructed of large coral blocks ( $p u^{\prime} a$ ) and ornamented with red feathers, a symbol of the most powerful ruling title. These sources collectively place the most ancient ceremonial centre of the Vaiari Chiefdom on the river bank in Titaaviri Valley, less than one kilometre inland (Fig. 2).

A second major ceremonial centre has been identified from a toponymic study of the district. In the land claim register three marae, Va'iōtaha, Taputapuatea and Hitia'a, were recorded on the land Taunoa, on the shore at the coastal promontory Rave-atau, facing the pass. Today this area is occupied by modern houses, but there are some poorly preserved remains; these 


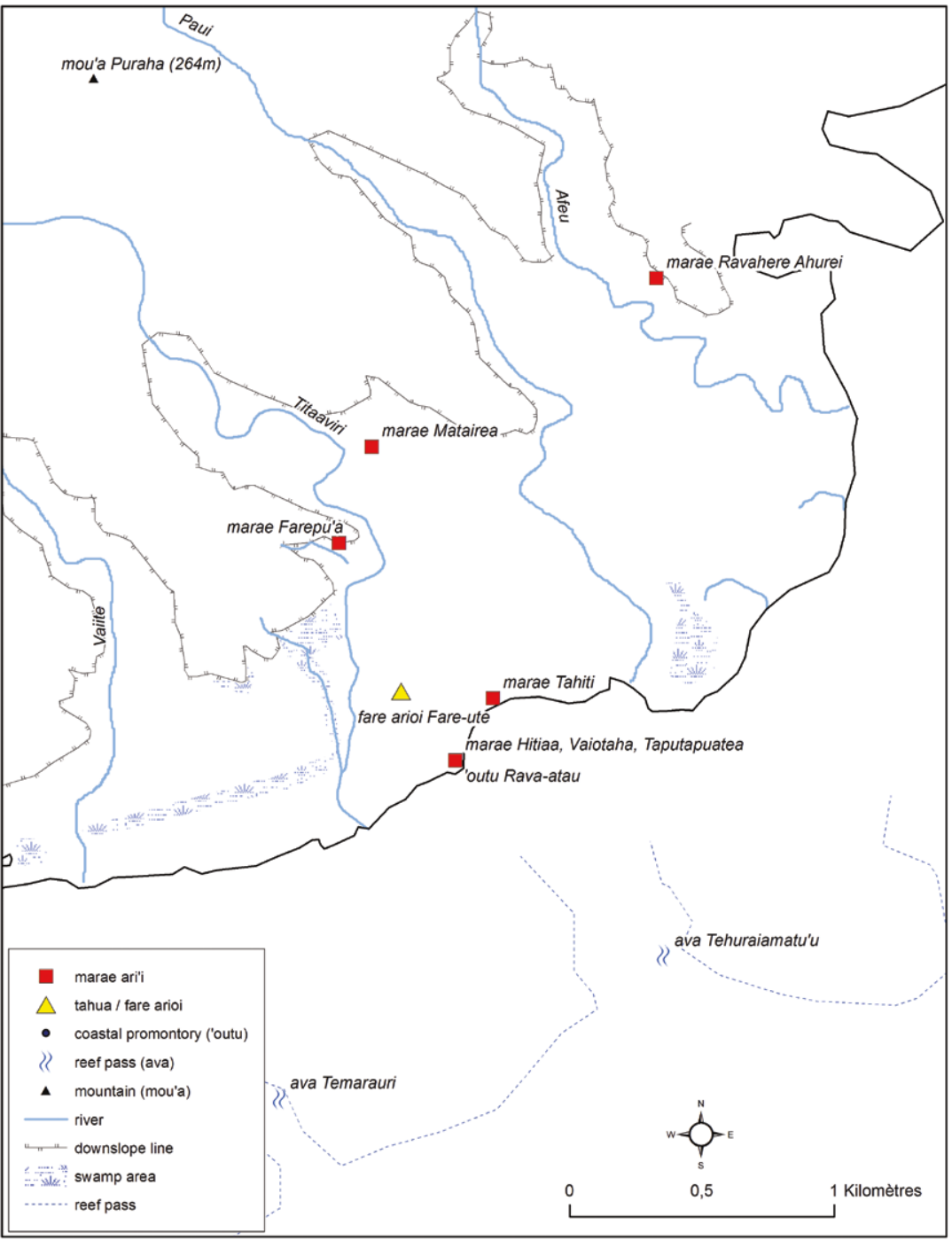

Figure 2. Location of ceremonial centres in Vaiari Chiefdom. 
include some squared coral blocks, upright basalt stones and a banyan tree, ${ }^{2}$ indicating the previous location of a marae. The local land names have kept the memory of ancient ceremonial places linked to the chiefdom, including the residence of the ari ' $i$, the house of 'arioi, ${ }^{1}$ and a place for high-ranking women (tapairu) (Maric 2012: 229). The marae of Taputapuatea in the district of Vaiari is recorded in several ethnohistorical accounts (Bodin 1982, Salmon 1951,Ta'aroa 1971). The Taputapuatea Marae of Vaiari is clearly related to the original Taputapuatea Marae in Opoa, and reflects expansionist activities during the proto-historic period (12 generations before AD 1900, c. the 17th century), according to the genealogy of Hiro (Cadousteau 1996: 34-36). Thus, there are two non-contemporaneous ceremonial centres in Vaiari District. The most ancient was located at Farepu'a Marae in Titaaviri Valley, and the more recent ones, marae Taputapuatea, Va'iōtaha and Hitia'a, were founded on the coastal promontory.

\section{PAPARA CHIEFDOM, TEVA I UTA CONFEDERATION, TAHITI ISLAND}

The Papara District and Chiefdom occupied a special location in the very steep topography of Tahiti. Here the deep and narrow valley opens onto a large coastal plain that is only $2 \mathrm{~km}$ wide, but is the largest coastal flat in the Society Islands. According to ethnohistorical sources, the chiefdom of Papara appeared after that of Vaiari. Traditions say the ancestor Teva was born of the Chiefess Hotutu (a descendant of the Vaiari lineage) and a chief who originated from Ra'iatea (Ta'aroa 1971). The latter is identified as Ari' $\mathrm{i}$ Matauhoe from marae Vaeara' $i$, in other words from Opoa on Ra'iatea. In this case, relative dating based on genealogies is difficult because of internal contradictions, with one indicating that Hotutu lived 40 generations before 1900 and the other suggesting 25 generations before 1900 (Pichevin 2013: 263). If we take the more recent one, Hotutu and Teva may have lived about the 15 th century (using a count of 20 years per generation).

Mata'oa Marae was founded on the coastal plain of Papara, close to the valley of Temarua (Fig. 3). In 1925, this marae was in a poor state of preservation, but Handy's [n.d.] unpublished journal records enclosure walls like those of the "coastal" type marae, and a sand mound that may correspond to the fill of an ahu platform. The site was excavated in 2004 (Maric et al. 2004), but nothing was left of the original marae, nor was there any stratigraphy; only buried and scattered round, shaped stones and squared quadrangular basaltic blocks were observed, which are surely the remains of the walls seen by Handy.

The most ancient chiefly marae in Papara was Taputuara' $i$, founded with one of the eight stones taken from the marae Vaeara' $i$ of Opoa (Ta'aroa 1971). It was situated in the ancient lands of Amo, at the beginning of Temarua Valley. The chiefly title linked to this marae was Tuitera'i (Adams 1964: 14). This 


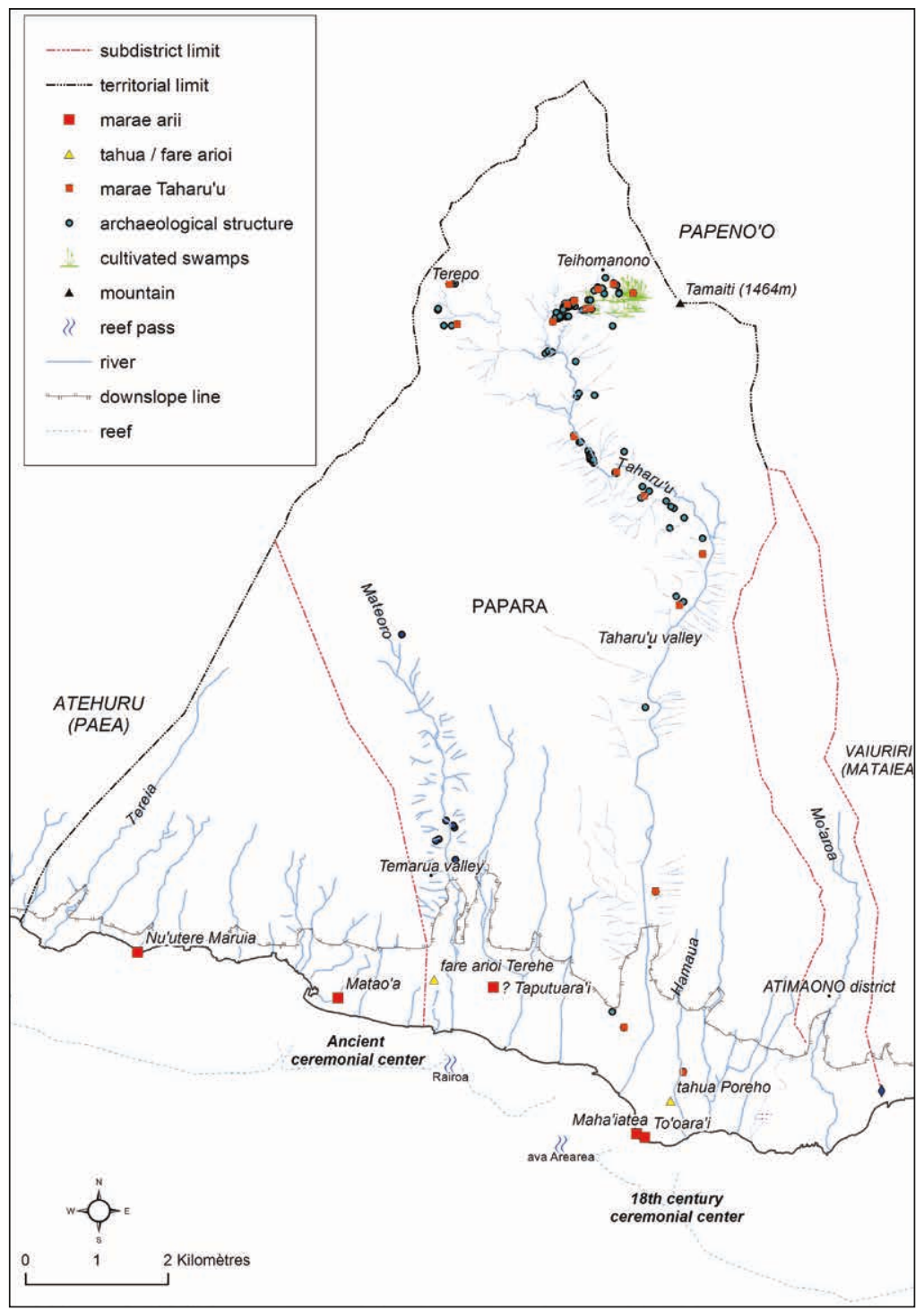

Figure 3. Location of the non-contemporaneous ceremonial centres in Papara Chiefdom. 
marae was recorded by Emory (1933: 74) as an "intermediate" type, with both enclosure walls and stepped $a h u$, and also simple architecture elements of the "coastal" type, such as round, shaped stones in the walls. It was associated with a smaller marae that was dedicated to the tutelary spirit of the $\operatorname{ari}^{\prime} i$ family. Unfortunately this marae was also destroyed during the 20th century.

In the 18th century, the ceremonial centre of Papara was transferred several kilometres to the west, to the coastal promontory of Manono at the mouth of the largest valley of the territory, Taharu'u (Fig. 3). This move can be linked with the historical account of Ari'i Taimai (Adams 1964) that relates a competition between the two brothers for the ari ' $i$ title, and which led to the exile of the oldest brother, Aromaitera' $i$. The younger brother, Amo, took a founding stone from the old family marae of Taputuara' $i$ and founded his own marae, To'oara' $i$, at Manono. To'oara' $i$ Marae stood on the shore and has been described as a typical "coastal" type marae, with enclosure walls and a two-step ahu platform (Baessler cited by Emory 1933: 34, Salmon 1913). Some years before the arrival of Captain James Cook, the monumental marae of Maha'iatea was constructed, close to the To'oara'i Marae.

The interior of Taharu' $u$, a steep and deep valley, is marked by scattered habitation sites, agricultural terraces and a few irrigated terraces. The settlement extended from the lower valley to the high plateau of Teihomanono (between 400 and $800 \mathrm{~m}$ elevation), and has been radiocarbon dated to the beginning of the 15th century. The first tangible occupations, in the lower valley as well as in the valley interior, are characterised by intense basalt flaking activities, which decrease over time. A ceremonial complex is found on the plateau, at an elevation of $600 \mathrm{~m}$, located at the edge of the cliff, while small habitation and horticultural sites are located along the streams (Maric 2012: 210-12). The ceremonial complex has been interpreted as indicative of ra 'atira residences, a class which is supposed to have played an intermediate role between the ari $i$ and the manahune in controlling the subsistence-production system.

All marae in Taharu'u Valley are of the "interior" type, from the little shrines associated with horticultural sites to a greater marae located at the feet of the sacred mountain Tamaiti and surrounded by a swamp. As this mountain is traditionally associated with the ari $i$ of Papara, it is larger and better constructed than all others in the valley; it may indicate a ceremonial site associated with the elite, and may also mark the inland margins of the chiefdom territory. The global settlement pattern of Taharu' $u$ Valley reveals an almost typical example of the ethnohistorical model: the ari ' $i$ ceremonial centre is located on the coast, and the lower classes are living in the mountains. This was the description given by the Teva descendants (Ta 'aroa 1971); however, the archaeological records show that the ethnohistorical model is too simple. 


\section{MANOTAHI CHIEFDOM (PUNA'AUIA), TAHITI ISLAND}

In the 18th century, Manotahi Chiefdom (the other ancient name of Puna'auia) formed, with Manorua or Paea, the confederation of Atehuru (also known as Te Oropa'a), and "the land of the warriors Manahune" (Handy 1930: 71). Douglas Oliver (1974: 976) classified it as of the fourth order of complexity. It is situated on the west side of Tahiti, and the main valley of Punaru' $u$ communicates with the interior of the caldera of Papeno'o. Traditionally, Puna'auia was populated by three original clans, with the Atiue and Mehiti (descendants from the founding ancestor Puna) occupying the interior and the Moene living on the coast (Handy 1930: 71).

The marae of Punaru'u Valley are all of the "interior" type, mostly grouped into aggregate complexes of marae. Some of them can be considered as monumental because of their dimensions, but they are not architecturally elaborated: natural blocks are used in the walls and facings of the $a h u$, except for some little slabs of coral. This fact can be underlined, as the elite presence through temple types is recorded in other major valleys of Tahiti and in 'OpunohuValley on Mo' orea. On the coast, although all marae have been destroyed archaeological records (Emory 1933; also unpublished records in Département Archéologie archives, Tahiti) describe monumental temples and $a h u$ with stepped platforms but constructed using only natural stones.

The most ancient marae ari ' $i$ of Manotahi was named marae Tahiti, and was founded from Farepu'a Marae in Vaiari, three generations before Teva (Cadousteau 1996, Emory 1927), and thus may date to shortly before the 15th century. Tahiti Marae was located $2 \mathrm{~km}$ from the coast in Punaru' $\mathrm{u}$ Valley (Fig. 4). It was visited by the Captain Wilson in 1797 who described a paved court of about 27 to $35 \mathrm{~m}$ wide, enclosed by wooden fences, and with a heap of stones corresponding to the $a h u$ platform (in Emory 1927: 100); the latter must have been a simple low platform of basalt stones. This type of $a h u$ platform can be compared with the second period of elaboration of marae B in the Ta ata Marae Complex in Paea (Garanger 1975). The remains recorded in 1920 by Handy and Emory (1933: 62-63) show a simple and small "interior" type marae with some coral slabs for the $a h u$, probably a marae annex, numerous platforms in a rocky steep area and sacred banyan trees.

In the 18th century, the major ceremonial centre of Manotahi was located on the coastal promontory of Nu'uroa, at the mouth of the Punaru'u River, where Taputapuatea Marae was founded near the more ancient marae of Puna'auia. This Taputapuatea Marae was also mostly destroyed when Emory (1933: 61-62) visited and recorded large coral slabs and numerous roundedshaped stones, which indicated a typical monumental "coastal" type marae.

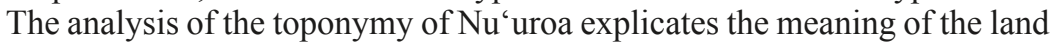




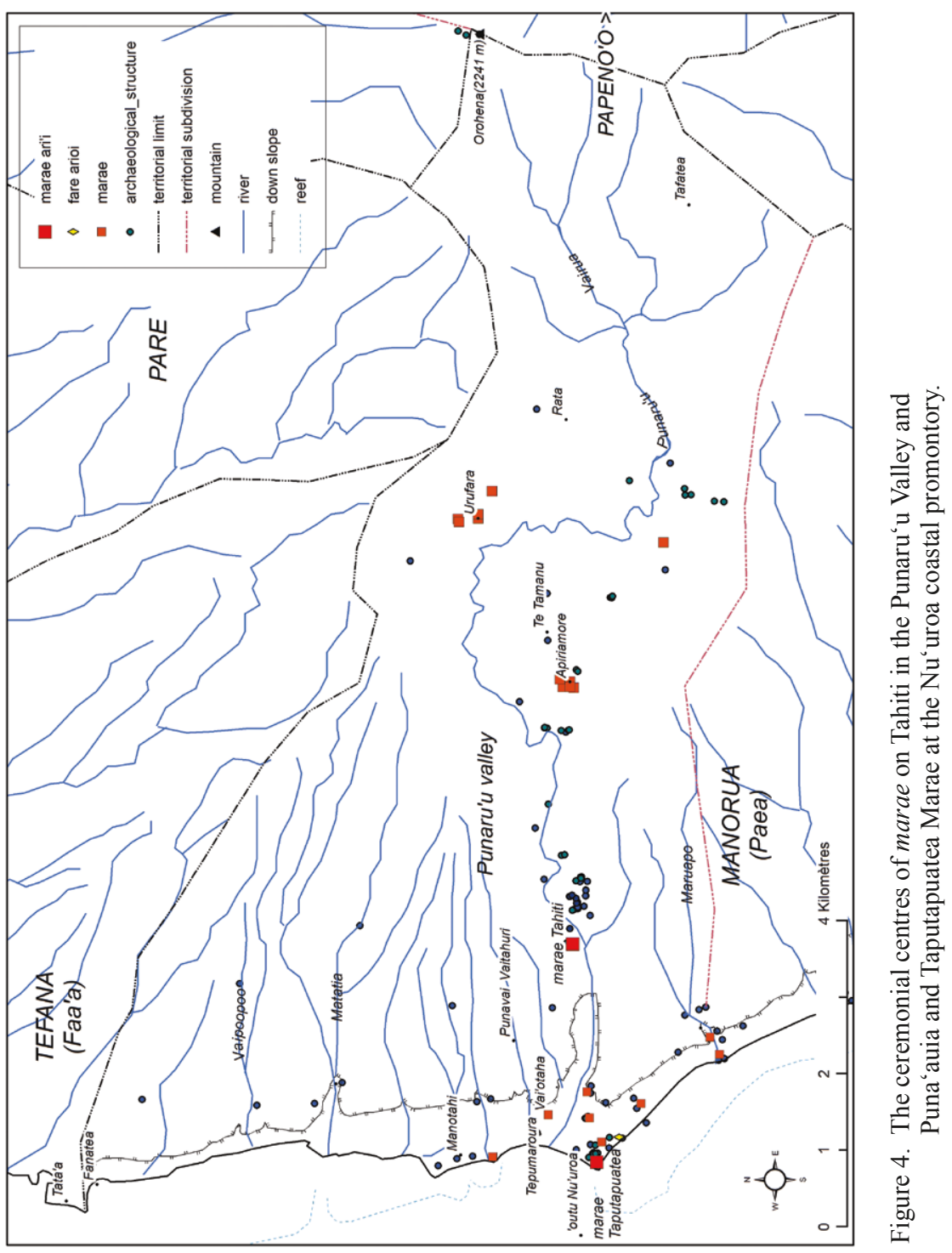


names, and shows different ceremonial spaces were associated with other districts and chiefly marae, fare 'arioi and so on (Tessier 2010).

In summary, the most ancient forms of the marae ari ' $i$ type were not architecturally elaborated temples, although they might have been monumental in size. In Puna'auia, the marae ari ' $i$ was located in the interior of the main valley of the district. The ceremonial centre of Taputapuatea, located on the coastal promontory at the mouth of this valley, must have been established later, around the late 17th to 18th centuries. We also know from ethnohistorical accounts that at the end of the 18th century the inland marae ari ${ }^{~} i$ were still in ritual use.

\section{CHIEFDOM OF OPOA, RA'IATEA, LEEWARD ISLANDS}

The pre-European political organisation of Ra'iatea, also named Havai' $i$, included nine principal chiefdoms. Opoa, located southeast of the island, was controlled by the ari ' $i$ Tamatoa who were considered the most powerful in the archipelago during the 17th to 18th centuries (Handy 1930: 83, Oliver 1974: 1209-10). Traditional lore relates that the god Ta'aroa arrived from the sky and placed his right foot on this locality (and his left foot on the other side of the island in the Tevaitoa Chiefdom). Then a marae was founded and named Vaeara' $i$ (literally 'feet from the sky') in the valley of Opoa (Handy 1930: 84). Vaeara' $i$ is located on the south river bank, not far from the valley mouth. Recorded in the early 1930s, Handy saw a disturbed pavement, an alignment of four basalt rocks and an upright basalt block (Emory 1927, 1933: 150).

Traditions say that stones were taken from Vaeara'i Marae for the foundation of new marae in both the Leeward and Windward Islands ( $\mathrm{Ta}^{\text {'aroa }}$ 1971). On Ra'iatea, the second marae founded from Vaeara' $i$ was the marae Tinirau Hui Mata te Papa o Fe'oro, dedicated to the god Ta'aroa and located on the coastal promontory Matahiraitera ' $\mathrm{i}$ in Opoa. This event involved moving the previous religious ceremonial centre, which had been located inland, to the coastal promontory where the marae faced the reef pass. During a later period, associated with the new god 'Oro, son of the god Ta'aroa, the marae was renamed Va'iōtaha. ${ }^{4}$ During the late pre-European period, the marae was renamed Taputapuatea. The family marae of the Tamatoa ari $i$, named Hauviri, was the seat of the principal religious rituals that punctuated the life and the death of the chiefs. The complex was also known as the seat of a religious "international" alliance, integrating other islands of the Societies, Rarotonga in the Cook Islands and maybe those as distant as Te Ao Tea Roa (New Zealand), Hawai 'i and Rotuma (Henry 2000: 128-30). ${ }^{5}$

The Taputapuatea Ceremonial Complex is located at Matahiraitera' $i$, where it is surrounded by natural boundaries and comprises a large sacred space named Te Pō. The site itself can be considered as a territorial limit, as it is 
situated on the boundary shared with the neighbouring district of Hotopu'u. The complex comprises four monumental marae, two smaller marae, and ceremonial and archery platforms. This site, along with the valleys of Opoa and Hotopu' $u$, is currently a candidate for UNESCO World Heritage status.

Emory and Sinoto (1965) first studied the Taputapuatea Ceremonial Complex in 1963. Subsequently, the principal marae were twice restored, first by Sinoto (1969) and then again between 1994 and 1995 by the Département Archéologie (Centre Polynésien des Sciences Humaines) of Tahiti. The impressive ahu platform measures $42.50 \mathrm{~m}$ in length by $8.20 \mathrm{~m}$ in width and is constructed of large, upright, coral slabs which reach $3 \mathrm{~m}$ in height (Fig. 5). An enclosure of square coral blocks is located at the summit of the $a h u$, corresponding to the ava 'a rahi described by Henry (2000: 140). When Emory and Sinoto (1965) conducted test excavations in the courtyard, they discovered a buried pavement level. While restoring the $a h u$ platform in 1969, Sinoto further observed that the prominent surface platform covered another older $a h u$ platform, of about the same dimensions in length but lower in height. So is the buried pavement contemporaneous with the first $a h u$ platform? Minimally we can say that the Taputapuatea Marae had at least two periods of construction, the second one seeing the development of

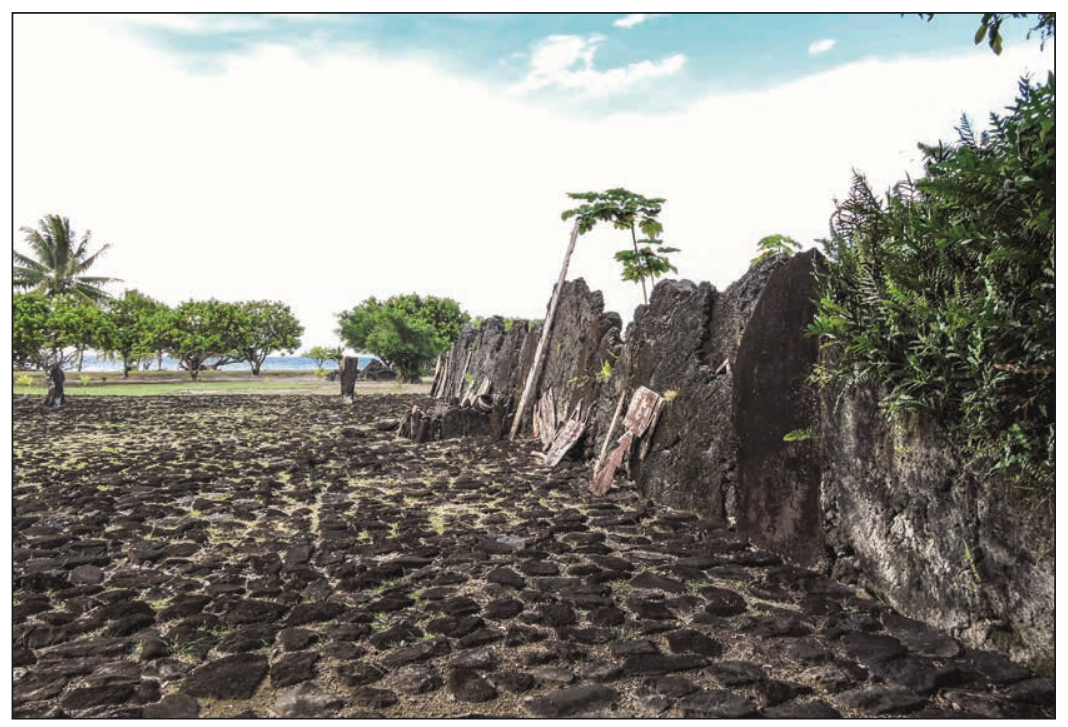

Figure 5. Coral slabs of the $a h u$ platform of Marae Taputapuatea (photo by author). 
monumental architecture. This matches with the oral traditions, which relate the consecutive names of this marae - first as Tinirau Hui Mata te Papa o Fe'oro, then as Vai'otaha, and finally Taputapuatea.

Taputapuatea Marae is one of the most monumental marae of the Leeward Islands, the largest being Tainu'u Marae in the Tevaitoa Chiefdom on the west coast of Ra'iatea; others include marae Anini in Huahine and marae Marotetini on Bora Bora (Emory 1933: 34). Tainu'u Marae may been constructed after Taputapuatea (Handy 1930: 91, Henry 2000), and if so would support the "developmental hypothesis", which suggests that the most monumental marae are a more recent phenomenon (Emory 1970: 77, Sinoto 2001: 17-21). This idea also is supported by ${ }^{230} \mathrm{U} / \mathrm{Th}$ dating of coastal marae ari ' $i$ on Mo'orea Island (Kahn and Kirch 2014: 45, Sharp et al. 2010: 13238), which demonstrated that the most monumental ones are later.

Turning to Hauviri Marae, this structure faces the lagoon and is flanked by another less monumental marae, currently known as 'Opu Teina. They both are separated by a little beach of about $15 \mathrm{~m}$ length named Taura'a-tapu. Hauviri Marae was fully restored in 1995 by the Département Archéologie, leading to a polemic about its final form, with Sinoto (2001) arguing that this marae was reconstructed with non-contemporaneous components. When Hauviri Marae was first recorded (Emory 1933) only an ahu platform and an upright stone of $2.7 \mathrm{~m}$ high in the courtyard were visible. Following the 1995 reconstruction, Hauviri Marae has a paved court enclosed by walls of a typical Windward Island marae form, with worked rounded basalt stones (of the "coastal" windward marae type) and mostly naturally rounded basalt pebbles. Despite the fact that no detailed report of the excavations and restoration is available, there are interesting data concerning this marae in the archives of the Service de la Culture et du Patrimoine in Tahiti (Navarro et al. 1995). During excavation of the court, the base of a double alignment of stones associated with scattered rounded stones, was interpreted as an ancient enclosure wall.

Otherwise, the stratigraphy clearly shows the absence of an underlying archaeological layer. This leads to the assumption that Hauviri was not founded on an earlier marae. Data on the $a h u$ platform are lacking, so it is not possible to confirm that the structure was never modified nor expanded. However, the absence of an underlying occupation, before the construction of Hauviri, can be interpreted as this site being later than Taputapuatea Marae. This would correspond to the ethnohistorical accounts: the successive names of Taputapuatea Marae suggest successive dedications and reconstructions, before the founding of the Tamatoa ari ' $i$ lineage associated with Hauviri Marae. If we allow that Hauviri once included worked stones typical of the "coastal" Windward marae type, then this would be a unique example 
of a typical Windward marae architectural component in a Leeward Islands setting. Other "coastal" type marae have been recorded in the mid-valley areas of Opoa (Edwards 1995a: 17), where a platform, courtyard and ahu platform with basalt slabs in the first course, and natural rounded pebbles in the walls, were found.

The settlement pattern of the Opoa Valley (Edwards 1995a, Niva 2008, 2009) shows habitation sites associated with irrigated horticultural terraces, and marae ranging from the "interior" type to simple shrines, the latter being the majority. One major ceremonial site of note, in the middle valley, is Taumariari Marae (Emory 1933: 150-51, Niva 2008) which includes a ceremonial platform with numerous upright stones, associated with two marae whose single $a h u$ are low platforms with small coral slabs and blocks in the facing, and simple marae annexe.

Returning to the Opoa case, the combined ethnohistorical and archaeological data allow for a preliminary hypothesis about the development of chiefly marae. The emergence of a ruling chiefly lineage here may be contemporaneous with the moving of the ceremonial centre from the original lower valley location to the coastal promontory, where the marae faced the sacred reef pass, and was at the limits of the territory of Opoa.

\section{DISCUSSION}

According to the oral traditions of Tahiti, several religious transformations are associated with the increasing pre-eminence of a god's worship. In the first stage there is the pre-eminence of Ta'aroa over Tane (Henry 2000), while in the pre-final stage 'Oro takes precedence over Ta'aroa. In the context of increasing social hierarchy, elites claimed divine ascendance and inter-married with the "royal" lineage of Tamatoa from Opoa on Ra'iatea which led to increasing status competition between ari $i$ lines. The founding of marae dedicated to the new worship involved the moving of the ceremonial chiefly centres to the coast, where they faced major reef passes, which became sacred.

Thus, the Tahitian and Opoa chiefdoms were spatially transformed through time. During the period of the establishment of the Tahitian chiefdoms, at a date still not firmly determined but perhaps c. 15 th century AD, the chiefly marae ari ' $i$ were located at the mouth of the principal valley of each territory, near the junction between inland and coastal zones. The precise architecture for most of these marae is unknown, but one note indicates the use of coral blocks or slabs in Farepu'a Marae from Vaiari. The testimony of Captain Wilson in 1797 regarding Tahiti Marae in Puna'auia (in Emory 1933: 62) suggests a simple architecture for this ancient and very prestigious marae ari $i$. The low basalt platform of the $a h u$ can be compared to other well documented and neighbouring sites. For example, at the Ta'ata Marae 
Complex, the structure designated marae $\mathrm{B}$ had three periods of architectural elaboration: at first the $a h u$ was a simple pavement, in the second period the $a h u$ was a low basalt platform, and in the third period, the $a h u$ was a three step platform, consistent with "coastal" type architecture (Garanger 1975). In the 'Opunohu Valley of Mo'orea, the marae of site ScMo-124 initially had an $a h u$ that was a low basalt platform, dated to the late 17th century; this was later followed by the addition of coral slabs to the $a h u$ of the principal marae (Kahn and Kirch 2014).

In the 17th and 18th century, in those localities, the ceremonial centres associated with the god 'Oro (Vai'ottaha and Taputapuatea Marae), and the chiefdom of Tamatoa from Opoa, were located on the shore, at coastal promontories and facing the reef pass. The former marae ari $i$ i were not abandoned and remained highly prestigious, but an important part of the principal ceremonies occurred at the coastal marae centres. It is unlikely that we will ever be able to date the foundations of these Tahitian marae, as they all have been completely destroyed, but the associated genealogies provide relative dates of around the end of the 17th century to the beginning of the 18 th century. At that time, worship of the god Ta' aroa persisted in Teva i Uta, while that of 'Oro from Opoa extended to most of other chiefdoms of Tahiti, including Tautira on the peninsula, Teva i Tai Confederation, Puna'auia, Paea, and probably Hitia'a and Papeno'o on the northeast coast.

The establishment of the new Taputapuatea Marae, and the associated major coastal ceremonial centres, corresponds to a new symbolic and spatial pattern whose origin is located in Opoa of Ra 'iatea. In moving the ceremonial centres to the seashore, at the mouth of the largest valley of the district, and facing the sea and sacred reef passes, the ari $i$ i were turned towards their powerful siblings in Ra'iatea.

Except for the first Taputapuatea Marae, established on Tahiti by the priests of Ra'iatea (Henry 2000), the foundation of the new marae Taputapuatea in the Windward Islands was the consequence of marriages between local chiefs and the Tamatoa lineage of Ra' iatea. Those alliances may have given more power and legitimacy to the local Tahitian chiefs who claimed their ascendance from the major gods of the Polynesian pantheon.

The development of ceremonial architecture with the "coastal" type components is dated at one site, Ahu o Mahine Marae the 'Opunohu Valley, from the 17th century, while others date to the 18th century (Kahn 2010). This architecture is considered an indicator of the 'Oro cult (Garanger 1980: 80 ) but, as it was recorded only in the Windward Islands, it was interpreted as a local innovation, leading to a possible contradiction: the cult of 'Oro directly originates from Ra'iatea, while the architectural "coastal" marae form linked with this worship appears to a local innovation of the Windward 
Islands. Nonetheless, archaeological data from the marae in Opoa show that this type of architecture also occurred on Rai'atea. Without dating, we can only propose the following hypothesis: an archaeological link exists between the first marae dedicated to "Oro in Opoa and the more recent "coastal" type marae on Tahiti and Mo"orea. On the other hand, the archaeology of the interior valleys of Ra'iatea is poorly known compared to the Windward Islands, with only three valleys archaeologically inventoried to date: $\mathrm{Fa}$ 'aroa and Opoa (Edwards 1995a, 1995b), along with Mitimitiaute Valley where eight marae have been recorded (Gérard 1974).

On Tahiti, the "coastal" type marae are located inland as well as on the coast. While local ari ' $i$ lines inter-married with the prestigious Leeward Island ari $i$ lines, especially with Tamatoa from Taputapuatea-Opoa, the ethnohistorical records give examples of competition initiated by junior lines. In Papara, this led to a junior chief usurping his senior and founding his own ceremonial centre in another place. The presence of this type of marae at far inland locations (e.g., 'Opunohu, Tautira and Papeno'o Valleys) also can be interpreted as the establishment of junior ari ' $i$ on new lands. Marae imitating the "coastal" architecture features, with natural (unmodified) stones, may also indicate the limited political power of those ari $i$ upon their people. ${ }^{6}$

In Opoa, the founding of the new marae on the coast is supposed to have occurred before the introduction of 'Oro worship. In Tahiti, however, the establishment of the new major district marae ari ' $i$ on the shore, associated with the 'Oro phenomenon, occurred later, probably during the 18th century, while the ari ' $i$ lineages captured increasing mana 'power' from their powerful siblings in Opoa. Did this have consequences for the settlement pattern of the district population as a whole? The expansion of the new 'Oro worship may have been of less importance for the lower social classes, and perhaps for the secondary ari $i$ as well (Eddowes 2001). The elite established the new religious and political order, while the common people continued to practice their own ancestral cults. But the ceremonies linked with ari $i$ i worship may have increased the need for ceremonial offerings (Robineau 1985: 167) and for goods for maintenance of the priestly class. Also, the need for more human sacrifices for 'Oro is emphasised by traditional sources (Henry 2000, Ta'aroa 1971), and this may have had dire consequences for the manahune. Also of note, high altitude settlements on Tahiti (500 to $1000 \mathrm{~m}$ ), associated with horticulture and the numerous simple marae or shrines, are testimony of an inland expansion into relatively unfavourable zones for agriculture. More archaeological research is needed to determine whether those settlements correspond to refuges or seasonal occupations. 
The hypothesis presented here is not necessary relevant to all Society Islands. We know, for example, that the pre-European settlement pattern of Huahine (in the Leeward Islands) was different, with a scattered territorial organisation of the whole population, including the elite (Saura 2005). The ceremonial centre, including the "national marae" of Matairea, was located in the uplands, on the Matairea Hill, and later ari ' $i$ founded a new ceremonial centre (Maeva) on the shore of Lake Fauna Nui. This tendency to reorganise ceremonial centres on the shores during the late pre-contact period remains to be fully interpreted. On Tahiti, during the second part of the 18th century, the wars between the Tahitian chiefdoms, legitimated by their Opoa siblings, increased. At the same time, competition between senior and junior chiefs inside their own lineages occurred. In this politically uncertain context, controlling the strategic coast, including the reef passes, and defending access to valley interiors, which were the major agricultural production areas, may have become necessary. As the foregoing suggests, the data presented in this paper will need to be considered in other areas, especially on Bora Bora where ari ' $i$ lineages also had a strong influence on the Tahitian chiefdoms but archaeological data about settlement patterns has yet to be studied. The case of Opoa also needs to be compared with further archaeological and ethnohistorical research relating to other chiefdoms on Ra'iatea Island.

\section{NOTES}

1. The society of 'arioi is defined as a kind of religious and artistic brotherhood, linked with worship of the god 'Oro, whose origins were in the Taputapuatea ceremonial centre of Ra'iatea Island.

2. Ficus prolixa, or ora in Tahitian, is a species commonly considered a sacred tree.

3. The Ta'ata Marae Complex is comprised of three courtyards (A, B, C) which are placed side-by-side and the three marae have differing architecture.

4. Many other ethnohistorical aspects are related to this site (Eddowes 2001) but space does not allow them to all be considered here.

5. While not published or well documented, some data exist about contacts between Taputapuatea in Opoa and Hawai' $\mathrm{i}$ (e.g., a heiau named Kapukapuakea) and New Zealand (i.e., genealogies).

6. Teuira Henry (2000) described the process of constructing marae ari ' $i$, with each family bringing stones, and sometimes giving their time and working under the control of the tahu 'a marae or 'specialist of marae construction'.

\section{REFERENCES}

Adams, Henry (ed.), 1964. Mémoires d'Arii Taimai. Publications de la Société des océanistes No. 12. Paris: Musée de l'Homme.

Bodin, Vonick, 1982. Langues Polynésiennes. Tahitien. Textes anciens; la légende de Hono-ura, Himene Paripari (Papeari), Fare ui api nō Tipaerui (Papeete, Mataiea, 
Pirae, Tamarii Fautaua). Unpublished report. On file, Service de la Culture et du Patrimoine, Te Anavaharau, Punaauia, Tahiti.

Cadousteau, Mai-Ari'i, 1996. Généalogies commentées des Arii des Iles de la Société. Papeete: Société des Études Océaniennes. 3rd edition.

Cauchois, Hinanui, 2010. Occupation de l'espace pré-européen et proto-historique de la vallée de Papetoai, à Mo'orea (îles de la Société). In Frédérique Valentin and Maurice Hardy (eds), Hommes, milieux et traditions dans le Pacifique Sud. Paris: Maison René-Ginouvès, Archéologie et Ethnologie, éditions De Boccard, pp. 67-81.

2015. Subsistence Systems and Defensive Strategies in Pre-Contact Mo'orea and the Society Islands, French Polynesia. Unpublished PhD thesis, University of Hawai'i at Manoa, Honolulu.

Eddowes, Mark D., 2001. Origine et évolution du marae Taputapuatea aux Iles Sous-le-Vent de la Société. Bulletin de la Société des Études Océaniennes: Papatumu-Spécial archéologie No. 289/290/291: 76-113.

_2003. Etude archéologique de l'île de Rimatara (Archipel des Australes). Dossier d'archéologie polynésienne No. 3. Punaauia, Tahiti: Ministère de la Culture de Polynésie Française, Service de la Culture et du Patrimoine.

Edwards, Edmundo, 1995a. Rapport. Prospection Archéologique de la Vallée d'Opoa. Raiatea-The Archeological Survey of the Valley of Opoa (Raiatea, Society Islands, French Polynesia). Unpublished report. On file, Département Archéologie, Centre Polynésien des Sciences Humaines, Te Anavaharau, Punaauia, Tahiti.

-1995b. Faaroa. Vallées de Vaiava, de la Huaroro et de la Papepao, île de Raiatea Commune de Taputapuatea, District d'Avera. Unpublished report. On file, Département Archéologie, Centre Polynésien des Sciences Humaines, Te Anavaharau. Punaauia, Tahiti.

Emory, Kenneth P., 1927. Traditional History of Maraes in the Society Islands. Typescript. On file, Bernice P. Bishop Museum, Archives, Honolulu.

1933. Stone Remains in the Society Islands. Bernice P. Bishop Museum Bulletin 118. Honolulu.

-1970. A re-examination of East-Polynesian marae: Many marae later. In Roger C. Green and Marion Kelly (eds), Studies in Oceanic Culture History, vol. I. Pacific Anthropological Records No. 11. Honolulu: Bernice P. Bishop Museum, pp. 73-92.

Emory, Kenneth P. and Yoshihiko Sinoto, 1965. Preliminary Report on Archaeological Investigations in Polynesia. Prepared for the Bernice P. Bishop Museum, Polynesian Archaeological Program, Honolulu.

Garanger, José, 1964. Recherches archéologiques dans le district de Tautira, Tahiti, Polynésie française. Journal de la Société des océanistes 20: 5-21.

1975. Marae Ta 'ata. Travaux effectués par la mission archéologique ORSTOMCNRS en 1973 et en 1974. CNRS RCP 259. Paris.

-1980. Prospections archéologiques de l'îlot Fenuaino et des vallées Aiurua et Vaiote à Tahiti. Journal de la Société des océanistes 66-67 (36): 77-104.

Gérard, Bertrand, 1974. Contribution à l'étude des structures lithiques à caractère religieux aux îles de la Société (Ethnologie-Archéologie): mémoire de stage. Papeete: ORSTOM. 
Green, Roger C., Kaye Green, Roy A. Rappaport, Ann Rappaport and Janet M. Davidson, 1967. Archeology on the Island of Mo'orea, French Polynesia. Anthropological Papers of the American Museum of Natural History 51, Part 2. New York.

Gunson, Niel, 1993. Understanding Polynesian traditional history. Journal of Pacific History 28: 139-58.

Handy, Edward Smith Craighill, 1930. History and Culture in the Society Islands. Bernice P. Bishop Museum Bulletin 79. Honolulu.

n.d. Journal I. Unpublished journal. On file, Bernice P. Bishop Museum, Archives, Honolulu.

Henry Teuira, 2000. Tahiti aux temps anciens. Publications de la Société des océanistes No. 1. Paris: Musée de l'Homme.

Kahn, Jennifer G., 2006. Society Islands (Central Eastern Polynesia) chronology: 11 radiocarbon dates for the late prehistoric expansion and protohistoric periods in the 'Opunohu Valley, Mo'orea. Radiocarbon 48 (3): 409-19.

2010. A spatio-temporal analysis of 'Oro cult marae in the 'Opunohu Valley, Mo‘orea, Society Islands. Archaeology in Oceania 45 (2): 103-10.

2011. Multi-phase construction sequences and aggregate site complexes of the prehistoric windward Society Islands (French Polynesia). Journal of Islands and Coastal Archaeology 6: 24-50.

2013. Temple renovations, aggregate marae, and ritual centers: The ScMo-15 complex, lower Amehiti District, 'Opunohu Valley, Mo'orea (Society Islands). Rapa Nui Journal 27 (2): 33-49.

Kahn, Jennifer G. and Patrick V. Kirch, 2014. Monumentality and Ritual Materialization in the Society Islands: The Archaeology of a Major Ceremonial Complex in the 'Opunohu Valley, Mo'orea. Bishop Museum Bulletin in Anthropology 13. Honolulu.

Maric, Tamara, 2012. Dyamiques de Peuplement et Transformations Socio-Politiques à Tahiti. 2 vols. Unpublished Thèse de Doctorat, Université de Paris 1, Panthéon Sorbonne, Paris.

Maric, Tamara, Christiane Dauphin and Belona Mou, 2004. Rapport de diagnostic archéologique sur le site du Marae Mataoa (commune de Papara, Tahiti). Unpublished report. On file, Service de la Culture et du Patrimoine, Te Anavaharau, Punaauia, Tahiti.

Métraux, Alfred, 1941. L'île de Pâques. Saint-Amand: Gallimard.

Navarro, Maeva, Joseph Tchong and Line Badalian, 1995. Mise en valeur du site de Taputapuatea, Opoa, Raiatea: Rapport préliminaire-juin 1995. Unpublished report. On file, Département Archéologie, Centre Polynésien des Sciences Humaines, Te Anavaharau, Punaauia,Tahiti.

Niva, Paul M., 2008. Rapport de prospection par système SIG dans la vallée d'Opoa, commune de Taputapuatea, île de Raiatea, 2008. Unpublished report. Service de la Culture et du Patrimoine, Te Anavaharau, Punaauia, Tahiti. 2009. Organisation et Sociologie d'un Territoire Pré-Européen: Le Cas d'Opoa, île de Raiatea (Archipel de la Société). Unpublished Mémoire de Master 1, Université de Paris 1. 
Oliver, Douglas, 1974. Ancient Tahitian Society. Honolulu: University Press of Hawaii. Pichevin, Bernard., 2013. Généalogies et Histoire des Tahiti et des îles de la Société. De prestigieuses lignées d'ari 'i. Papeete: Au Vent des Iles.

Robineau, Claude, 1985. Du coprah à l'atome. Tradition et modernité aux îles de la Société. Les Racines (Tome II). Paris: ORSTOM.

Salmon, Tati, 1910. On ari ' $i$ in Tahiti. Journal of the Polynesian Society 19 (1): 39-46.

-1913. Manuscript of Tati Salmon (loaded by Moti): The oldest great Tahitian maraes and the last one built in Tahiti, p. 25, No. 85, Mars 1913. Bernice P. Bishop Museum Archives, Honolulu.

1951. L'histoire de l'île de Bora-Bora et la généalogie de notre famille du marae Vaiōtaha. Bulletin de la Société des Études Océaniennes Tome VIII, No. 97: 315-30.

Saura, Bruno, 2005. Huahine aux temps anciens. Cahiers du Patrimoine No. 8, Savoirs et Traditions: Tradition Orale. Punaauia, Tahiti: Service de la Culture et du Patrimoine de Polynésie Française.

Sharp, Warren D., Jennifer G. Kahn, Christina M. Polito and Patrick V. Kirch, 2010. Rapid evolution of ritual architecture in central Polynesia indicated by precise 230Th/U coral dating. Proceedings of the National Academy of Sciences 107 (30): 13224-39.

Sinoto, Yoshihiko, 2001. Questions de restauration. Le cas des marae des Iles de la Société. Bulletin de la Société des Études Océaniennes, Papatumu-Spécial archéologie No. 289/290/291: 5-32.

Ta'aroa, Marau, 1971. Mémoires de Marau Taaroa. Dernière reine de Tahiti. Traduits par sa fille la Princesse Ariimanihinihi Takau Pomare. Publications de la Société des océanistes No. 27. Paris: Musée de l'Homme.

Te Reo o te Tuamotu (Collectif), 2000. Tuamotu te kaiga. Langes et Cultures. Quête identitaire et affirmation culturelle. Tahiti: Haere Po.

Tessier, Vairea, 2010. Hiti frontière première et originelle. Mai 'Orohena e haere roa atu i Nu'uroa. Carte toponymique. Punaauia, Tahiti: Musée de Tahiti et des Iles.

Torrente, Frédéric, 2010. Ethnohistoire de Anaa. Un Atoll dans les Tuamotu. Unpublished Thèse de Doctorat, Université de la Polynésie Française, Papeete.

_2012. Buveurs de mer, mangeurs de terres, histoire des guerriers d'Anaa, atoll des Tuamotu. Papeete: Te Pito o te fenua.

Vaimeho-Peua, Eliane T., 2008. La Toponymie des Terres de Faa 'a (île de Tahiti) et les Représentations Foncières Tahitiennes. Unpublished Thèse de Doctorat, Université de la Polynésie Française, Papeete.

Wallin, Paul and Reidar Solsvik, 2005. Radiocarbon dates from marae structures in the district of Maeva, Huahine. Journal of the Polynesian Society 114 (4): 375-83.

\section{ABSTRACT}

This article compares the geographic and organisational patterns of four major chiefly ceremonial places in the Society Islands. On the island of Tahiti, archaeological data relating to monumental temple (marae ari $i$ ) architecture is integrated with ethnohistoric records and toponymic analysis to reconstruct local ethnohistories of 
the Tahitian chiefdoms of Vaiari, Papara and Manotahi (Puna'auia). The ethnohistoric records identify a shift in the location of major religious and ceremonial centres, from original inland locations to coastal sites, around the end of the 17th and 18th centuries in the context of strong political influences from the Leeward Society Islands. The patterns of late Tahitian ceremonial complexes are compared with archaeological and ethnohistorical data from the chiefdom of Opoa on Ra'iatea Island, where the same model of spatial and diachronic evolution seems to have previously occurred. This analysis suggests that chiefdom of Opoa, focused on the great marae Taputapuatea, had a strong influence on Tahitian polities, through the foundation of new marae Taputapuatea in the Windward Islands and accompanied by new boundaries which demarcated sacred landscapes.

Keywords: Settlement patterns, ceremonial architecture, marae, ethnohistory, toponymy, Society Islands, Polynesian chiefdoms

\section{CITATION AND AUTHOR CONTACT DETAILS}

Maric, ${ }^{1}$ Tamara, 2016. From the valley to the shore: A hypothesis of the spatial evolution of ceremonial centres on Tahiti and Ra'iatea, Society Islands. Journal of the Polynesian Society 125 (3): 239-262. DOI: http//dx.doi.org/10.15286/ jps.125.3.239-262

${ }^{1}$ Correspondence: Laboratoire d'Ethnologie préhistorique - UMR 7141—Université de Paris X Nanterre, Paris, France; Service de la culture et du patrimoine-Pu no te ta'ere e no te faufa'a tumu, Punauuia, French Polynesia; Centre international de recherche archéologique polynésienne (CIRAP) Université de Polynésie française. Email: tamara.maric@culture.gov.pf 